This Journal is available in Telkom University online Journals

Jurnal Manajemen Indonesia

\title{
Iklim Organisasi pada Perusahaan Manufaktur Karoseri PT. Karoseri SUS
}

Andhika Alexander Repi

Fakultas Psikologi, Universitas Katolik Widya Mandala Surabaya, Surabaya, Indonesia

\begin{abstract}
The organizational climate determined performance of organization member's organization itself. A conducive organizational climate causes productivity to increase, and vice versa. The karoseri manufacturing companies PT. Karoseri SUS have an un-conducive organizational climate, but the members and organization in general are still able to perform well. The karoseri manufacturing company itself is a type of company that is unique and different from other manufacturing industries. The purpose of this study is to identify the dimensions that forming the organizational climate in a karoseri manufacturing company in PT. Karoseri SUS. This study used a qualitative approach to the type of case study research. Data was collected through interviews with 6 representatives of employees of karoseri manufacturing companies in Surabaya. Inductive thematic analysis is used as a data analysis technique. The results of the study show that the dimensions of organizational climate at karoseri manufacturing companies PT. Karoseri SUS formed by application of management systems, social environment, physical environment, and habit patterns in the organization. Each of these dimensions is also formed by the components, which are the dimensions of the management system consisting of work standards and procedures, reward systems, and bureaucratic systems, social environment dimensions consisting of relationships between superiors and subordinates, relationships between colleagues, and relationships between organizations and outside parties, the dimensions of the physical environment consist of facilities, facilities and infrastructure supporting work processes and dimensions of habitual patterns in the organization which consist of habits and attitude which bring impact to work process.
\end{abstract}

Keywords-Organization Climate, Manufacture Karoseri Industry, Organizational Development

\begin{abstract}
Abstrak
Iklim organisasi dapat menjadi penentu kinerja anggota dan organisasi secara keseluruhan. Iklim organisasi yang kondusif menyebabkan produktivitas meningkat, dan berlaku sebaliknya. Perusahaan manufaktur karoseri PT. Karoseri SUS memiliki iklim organisasi yang kurang kondusif, namun anggota organisasi dan kinerja organisasi secara keseluruhan tergolong produktif. Perusahaan manufaktur karoseri itu sendiri merupakan jenis perusahaan yang unik dan berbeda dengan industri manufaktur lainnya. Tujuan penelitian ini untuk mengidentifikasi dimensi pembentuk iklim organisasi di perusahaan manufaktur karoseri di PT. Karoseri SUS. Penelitian ini menggunakan pendekatan kualitatif dengan tipe penelitian studi kasus. Data dikumpulkan melalui wawancara pada 6 perwakilan karyawan perusahaan manufaktur karoseri di Surabaya. Inductive thematic analysis digunakan sebagai teknik analisis data. Hasil penelitian menunjukkan dimensi pembentuk iklim organisasi di perusahaan manufaktur karoseri PT. Karoseri SUS terdiri dari penerapan sistem manajemen, lingkungan sosial, lingkungan fisik, dan pola kebiasaan dalam organisasi. Setiap dimensi tersebut pun dibentuk oleh komponen penyusun, yaitu dimensi sistem manajemen terdiri dari standar dan prosedur kerja, sistem imbalan, dan sistem birokrasi, dimensi lingkungan sosial terdiri dari hubungan antara atasan dengan bawahan, hubungan antar rekan kerja, dan hubungan antara organisasi dengan pihak luar, dimensi lingkungan fisik terdiri dari fasilitas, sarana dan prasarana pendukung proses kerja serta dimensi pola kebiasaan dalam organisasi yang terdiri dari sikap-sikap yang biasa dilakukan organisasi dan berdampak pada proses kerja.
\end{abstract}

Kata Kunci- Iklim Organisasi, Perusahaan Manufaktur Karoseri, Pengembangan Organisasi 


\section{PENDAhUluan}

Wirawan (2008) dan Stinger (2002) menjelaskan bahwa iklim organisasi merupakan persepsi seluruh anggota organisasi dan pihak yang secara rutin berdinamika bersama organisasi tersebut dan menjadi penentu individu untuk berperilaku serta pemicu motivasi untuk melakukan suatu pekerjaan. Informasi mengenai iklim organisasi yang ada di dalam suatu perusahaan dapat dijaring dari persepsi semua yang terlibat dalam perusahaan tersebut, yaitu persepsi manajer (white collar worker), persepsi karyawan pelaksana (blue collar worker), serta persepsi orang luar seperti pemasok, konsumen, dan konsultan yang berhubungan dengan orgnaisasi tersebut secara tetap (Wirawan, 2008).

Iklim organisasi hadir di semua organisasi termasuk di perusahaan manufaktur karoseri. Perusahaan manufaktur karoseri merupakan industri yang secara khusus bergerak pada bidang pembentukan atau merakit bahan dasar seperti logam, kaca, karet dan sebagainya, komponen setengah jadi seperti pick up untuk dijadikan kendaraan seperti bus, truck, trailer, semi-trailer, dan sebagainya. Adapun proses manufaktur di bidang karoseri meliputi pemotongan bahan dasar, las, press, cat, dan sebagainya. Biasanya, hasil produksi dari perusahaan ini digunakan sebagai angkutan logistik. Industri ini termasuk pada industri perakitan padat karya, dengan proses produksinya yang bersifat manual serta diperlukan keterampilan manusia (Satwiko, 1991). Keunikan dari perusahaan manufaktur karoseri adalah pada jenis usahanya, dimana proses produksinya berdasarkan pesanan dari pelanggan dan tidak menyediakan stock barang (made by order). Artinya, produk karoseri hanya akan dibuat jika ada pesanan, dan pesanan tersebut pun didasarkan pada keinginan pelanggan. Pembuatan berdasarkan pesanan yang dimaksud meliputi model, bentuk, serta ukuran sehingga antar suatu produk akan berbeda (Abdurrochman, 2010).

Berdasarkan pemaparan di atas, idealnya, iklim organisasi yang kondusif akan berkorelasi positif dengan kinerja yang produktif. Jika para karyawan memiliki persepsi bahwa pekerjaan serta lingkungan kerjanya nyaman dan kondusif, maka kualitas kerjanya pun akan meningkat. Namun, gambaran tersebut berbanding terbalik dengan hasil pre-liminary research pada perusahaan manufaktur karoseri PT. Karoseri SUS. Anggota organisasi PT. Karoseri SUS mengeluhkan berbagai fasilitas yang diberikan oleh perusahaan termasuk imbalan. Menurut beberapa pihak yang diwawancarai, para anggota memiliki peran vital dalam proses produksi, seperti menerima order, mendesain, hingga membuatkan orderan sesuai keinginan customer. Namun, kompensasi dan fasilitas yang diterima tidak sesuai. Bagian produksi pun mengeluhkan hal yang serupa bahwa meski banyak orderan yang masuk ke perusahaan, perusahaan tidak secara transparan dalam menginfokan keuntungan dan tidak adanya penambahan bonus kepada mereka. Permasalahan lain yang muncul di PT. Karoseri SUS, yaitu terkait kepemimpinan. Pemimpin di perusahaan tersebut berjumlah 4 orang dan keempatnya memberikan tugas kepada para karyawan dalam satu waktu yang sama. Permasalahan kepemimpinan ganda ini akhirnya membuat para karyawan pun menjadi bingung dengan job-descnya. Dari divisi human resources pun tidak memiliki inisiatif untuk memperjelas deskripsi pekerjaan dari semua divisi yang ada. Sehingga, berdasarkan penjelasan tersebut, lingkungan kerja di PT. Karoseri SUS tergolong kurang menyenangkan dan terindikasi memiliki iklim organisasi yang tidak kondusif

Iklim organisasi yang kurang kondusif membuat karyawan tidak puas, tidak bahagia, dan tidak nyaman terhadap pekerjaan serta organisasinya. Jika hal ini dibiarkan, para karyawan akan banyak mengeluh, membangkan, tingginya angka absen, menurunnya kinerja karyawan, meningkatnya kesalahan dalam bekerja, hingga keluar dari perusahaan (Idrus, 2006, Luthans, 2006, dan Wirawan, 2008). Hal senada diungkapkan oleh Adenike (2011), dan Dewi \& Prasetyo (2017) bahwa karyawan yang tidak bahagia dan tidak puas dengan pekerjaannya akan menghasilkan kinerja yang buruk dan bahkan banyak karyawan yang akan keluar dari perusahaan tersebut. Berdasarkan data yang diperoleh dari bagian human resources department, karyawan pun mengalami hal serupa dimana banyak karyawan yang terlambat lima hingga lima belas menit dari jam masuk dalam rentang enam bulan terakhir, serta tingginya tingkat turn over yang mencapai lebih dari $13 \%$ dalam tiga bulan terakhir. Keluhan karyawan yang masuk di human resources department mengenai sistem kerja dan kepemimpinan pun meningkat dalam kurun waktu 1 tahun ini.

Indikasi iklim organisasi yang kurang kondusif ini seharusnya berdampak pada kinerja perusahaan secara umum, seperti turunnya kualitas produk dan berimbas pada turunnya omzet dan pemesanan karoseri dari para customer di PT. Karoseri SUS. Namun, sebaliknya, kinerja dari PT. Karoseri SUS memadai yang ditunjukkan dengan adanya peningkatan omzet dan jumlah pesanan karoseri bahkan hingga lima kali lipat. Jumlah customer yang baru meningkat $25 \%$ dalam rentang enam bulan terakhir. Dari hasil survey kepuasan customer terhadap produk PT. Karoseri SUS yang diadakan oleh pihak human resources department bekerjasama dengan sales and marketing department pun berada pada kategori cukup puas hingga puas. 
Jika iklim organisasi tidak kondusif, maka karyawan pun akan memiliki produktivitas kerja yang rendah. Secara praktis, hal ini seharusnya berdampak pada turunnya permintaan pembuatan karoseri serta turunnya omzet PT. Karoseri SUS. Senyatanya, meski menunjukkan adanya gejala iklim yang kurang kondusif, kinerja karyawan dan organisasi PT. Karoseri SUS cenderung baik. Konsep teoritis iklim organisasi yang berbanding terbalik dengan hasil preliminary research membuat peneliti tertarik untuk mengidentifikasi lebih dalam mengenai variabel iklim organisasi di perusahaan manufaktur karoseri di PT. Karoseri SUS. Adapun tujuan penelitian ini untuk menganalisis dimensi pembentuk iklim organisasi pada perusahaan manufaktur karoseri PT. Karoseri SUS.

Hasil penelitian diharapkan dapat memberi gambaran mengenai dimensi apa saja yang membentuk iklim organiassi di perusahaan manufaktur karoseri PT. Karoseri SUS dan dapat menjadi masukan untuk pengembangan organisasi serta optimalisasi kinerja anggota. Selain itu, hasil penelitian diharapkan dapat memperkaya teori mengenai perilaku organisasi khususnya iklim yang terbentuk pada perusahaan manufaktur karoseri. Temuan dimensi pembentuk iklim organisasi dengan Informan penelitian perusahaan manufaktur karoseri diharapkan menjadi salah satu referensi teoritik yang dapat digunakan untuk mengeksplorasi lebih dalam mengenai variabel iklim organisasi pada organisasi sejenis.

\section{KAJIAN LITERATUR DAN PENGEMBANGAN HiPOTESIS}

\section{A. Perusahaan Manufaktur Karoseri}

Kata karoseri berasal dari beragam bahasa seperti di Perancis menyebutnya sebagai Carrosserie, bahasa Jerman menyebutnya Karosserie, dan di bahasa Italia menuliskannya sebagai Carrozziere. Namun, pada dasarnya, karoseri merupana suatu usaha jasa dalam membuat bodi serta desain interior suatu kendaraan (Abdurrochman, 2010). Jika menilik ke konsep usahanya, perusahaan karoseri dikategorikan sebagai perusahaan manufaktur jasa karena sebagain besar produksinya adalah made to order (dibuat jika ada pesanan) bukan made to stock (dibuat sebagai stok untuk dijual). Karoseri memiliki kekhasan khususnya dalam proses pembuatan manual untuk bodi kendaraan. Maksudnya, pembuatan karoseri ini juga biasanya didasarkan pada permintaan pemesan secara khusus (customize) sehingga satu produk dengan produk yang lain tidak menetap (Abdurrochman, 2010).

Perkembangan industri manufaktur karoseri di Indonesia mengalami kondisi yang fluktuatif dalam rentang tahun 2016-2018. Gabungan Industri Kendaraan Bermotor Industri atau Gaikindo merilis Indonesian Automobile Industry Data bahwa produksi produk karoseri mengalami peningkatan, yaitu 205.101 unit pick up/truck dan 4769 unit bus di tahun 2016, 233.219 unit pick up/truck dan 2500 unit bus di tahun 2017, dan 237.842 unit pick up/truck dan 2908 unit bus di tahun 2018. Dari data penjualan (wholesales) pun menunjukkan angka yang fluktuatif. Penjualan produk bus di tahun 2016 mencapai 3959 unit, turun di tahun 2017 menjadi 3598 unit, dan tetap turun pada periode Januari-Oktober 2018 dengan angka 3001 unit. Begitu pula dengan penjualan produk pick up dan truck yang mencapai angka 187.428 unit di tahun 2016, kemudian naik di tahun 2017 dengan angka 217.626 unit, dan turun kembali pada periode Januari-Oktober 2018 dengan total penjualan 213.380 unit (sumber data: https://www.gaikindo.or.id/indonesian-automobile-industry-data/).

\section{B. Iklim Organisasi}

Para ahli organisasi belum menemukan titik temu mengenai arti yang definitif tentang apa yang dimaksud dengan iklim organisasi. Forehand \& Gilmer (1964) menarik suatu kesimpulan bahwa iklim organisasi merupakan suatu trait yang membedakan antara satu organisasi dengan yang lainnya. Davis dan Newstrom pada tahun 2001 menyebutkan bahwa iklim merukan suatu kepribadian dari organisasi. Wirawan (2008) mendefinisikan iklim organisasi sebagai persepsi anggota organisasi baik individu maupun kelompok termasuk pihak yang secara konsisten berinteraksi dengan organisasi seperti pemasok, konsumen, konsultan, dan sebagainya, tentang apa yang terjadi di lingkungan organisasi dan memengaruhi sikap, perilaku, kinerja anggota dan organisasi serta refleksi atas nilai pribadi dan keinginan secara psikologis. Berbagai definisi dari iklim organisasi dapat disederhanakan menjadi suatu gambaran perasaan para anggota organisasi dan pihak lain yang berinteraksi dengan organisasi secara rutin mengenai apakah organisasi tersebut menyenangkan atau tidak, kondusif atau tidak, positif atau tidak.

Wirawan (2008) menjelaskan bahwa perbedaan iklim antar organisasi disebabkan oleh faktor-faktor yang menimbulkan perbedaan. Iklim ini ditentukan oleh lingkungan eksternal dan internal. Lingkungan internal yang menentukan iklim organisasi merupakan semua dimensi pembentuknya. Berbagai ahli menjabarkan tentang dimensi iklim organisasi, seperti Stinger (2002) yang menyebutkan bahwa iklim organisasi disusun dari dimensi 
struktur, standar-standar, tanggung jawab, penghargaan, dukungan serta komitmen. Wirawan (2008) menjabarkan bahwa iklim organisasi dibentuk dari dimensi keadaan lingkungan fisik tempat kerja, keadaan lingkungan sosial, pelaksanaan sistem manajemen, produk, konsumen, klien dan nasabah yang dilayani, kondisi fisik dan kejiwaan anggota organisasi, serta budaya organisasi. Penelitian Permarupan et al (2013) menggunakan aspek transparansi, standar, akuntabilitas, dukungan dan penghargaan, serta komitmen tim sebagai penyusun iklim organisasi.

\section{Keterkaitan antara Iklim Organisasi dengan Perusahaan Manufaktur Karoseri}

Industri karoseri memiliki suatu keistimewaan dibandingkan dengan industri manufaktur lainnya. Keistimewaan tersebut ditunjukkan dengan proses kerjanya yang termasuk made to order (dibuat berdasarkan pesanan). Dalam arti, jika ada pesanan, maka produk tersebut baru dibuat bukan seperti perusahaan manufaktur lainnya yang memproduksi sesuatu untuk di stok (made to stock). Selain itu, keistimewaan lainnya adalah satu produk dengan produk lainnya yang dihasilkan pun berbeda-beda karena tergantung dari permintaan pemesan (customize) (Abdurrochman, 2010). Dengan demikian, diperlukan kemampuan serta kualitas sumber daya manusia yang terbaik karena terkait hasil produk yang berkualitas (Astuti, 2010). Adapun indikator keberhasilan industri karoseri dilihat berdasarkan tingginya permintaan pasar terhadap produksi karoseri seperti bus, truck, dump truck serta thriller serta rendahnya komplain dari para pelanggan.

Jika menilik pada perkembangan di Indonesia, industri manufaktur karoseri nasional masih fluktuatif. Fluktuatifnya perkembangan industri karoseri ini tidak dapat menghindarkan berbagai perusahaan terpaksa gulung tikar. Dalam upaya pengendalian kualitas industri, secara khusus perusahaan manufaktur karoseri, perlu adanya pengembangan berkelanjutan terhadap berbagai komponen, yaitu, manusia, mesin/peralatan, material, dan metode (Abdurrochman, 2010; Astuti, 2010; Permarupan et al, 2013; Muthukumar dan Guru, 2016; dan Yadav, Balaji, dan Narendra, 2016). Seluruh komponen tersebut akan berpengaruh terhadap iklim yang terbentuk di organisasi perusahaan manufaktur karoseri.

Iklim organisasi merupakan komponen yang sangat penting dalam organisasi. Iklim organisasi yang kondusif akan berkorelasi positif dengan komitmen kerja, produktivitas kinerja, serta kepuasan kerja (Permarupan, et al, 2013; Bahrami, et al, 2016; Mutukhumar \& Guru, 2016; Li \& Mahadevan, 2017). Iklim yang kondusif ditunjukkan dengan berbagai hal seperti sarana kerja yang ada cukup lengkap untuk mendukung pekerjaan, ruang kerja nyaman, deskripsi pekerjaan yang jelas, adanya hubungan yang baik dan hangat dengan atasan maupun rekan kerja, serta adanya penghargaan bagi yang berprestasi dan sanksi bagi yang melanggar aturan. Bagi perusahaan karoseri sendiri, lingkungan kerja yang kondusif adalah ketika perusahaan mampu menerapkan sistem kerja yang efisien dan efektif serta sarana dan prasarana yang lengkap disediakan oleh pihak atasan (Stinger, 2002; Wirawan, 2008; Dewi \& Prihatsanti, 2010; Björkdahl \& Börjesson, 2011; Dewi \& Prasetyo, 2017; dan Simamarta, et al, 2017). Sebaliknya, ketika karyawan merasa lingkungan kerjanya kurang kondusif, maka ia akan mempersepsikan bahwa iklim yang hadir adalah negatif pula. Iklim negatif ini akan menyebabkan karyawan tidak puas dengan pekerjaannya dan menganggap lingkungan kerjanya tidak menyenangkan yang kemudian berdampak pada penurunan kinerja baik secara individual maupun organisasi.

Setiap organisasi memiliki iklimnya masing-masing secara spesifik (Li \& Mahadevan, 2017), termasuk di perusahaan manufaktur karoseri. Secara spesifik, Hsu (dalam Muthukumar dan Guru, 2016) menyebutkan bahwa di organisasi dengan tipe industri manufaktur, lingkungan kerja serta iklim organisasi dibentuk oleh berbagai hal seperti otonomi, integrasi, partipasi, dukungan penyelia, pelatihan, kesejahteraan, inovasi dan fleksibilitas, fokus ke hal diluar organisasi, reflektif, kejelasan tujuan organisasi, efisiensi, usaha, umpan balik dari kinerja, formalisasi, tekanan untuk memproduksi suatu hal, serta tradisi dan kualitas. Sehingga, aspek penyusun iklim organisasi pun menjadi begitu variatif, spesifik dan sesuai karakteristik organisasi yang menyusun iklim di tempat tersebut. Bahkan, para pakar iklim organisasi mengidentifikasi paling tidak terdapat 460 jenis lingkungan kerja dengan masing-masing iklim organisasinya (Rob Altman dalam Wirawan, 2008: 128). Perbedaan ini dikarenakan lingkungan organisasi satu dengan yang lain berbeda-beda (Dewi \& Prihatsanti, 2010). Umstot (dalam Idrus, 2006) menyatakan bahwa faktor tertentu dapat penting pada organisasi tertentu, namun tidak memiliki makna yang berarti pada organisasi lain. Dengan demikian, iklim organisasi beserta dimensi pembentuknya tidak dapat disamakan antar satu organisasi dengan organisasi yang lain karena berbagai hal seperti ruang lingkup perusahaan, fokus pekerjaan, serta berbagai macam hal lainnya. Begitu pula iklim organisasi yang ada di perusahaan manufaktur karoseri diduga dibentuk oleh dimensi yang berbeda pula. 


\section{METODE PENELITIAN}

\section{A. Metode/Rancangan penelitian}

Metode penelitian yang digunakan, yaitu penelitian kualitatif. Metode penelitian kualitatif dapat memberikan gambaran mendalam tentang tingkah laku individu yang tampak, maupun kondisi internal di dalam diri seperti self-values, dan pandangan hidup maupun persepsinya terhadap lingkungannya, termasuk mampu mengungkap aspek-aspek yang relevan terkait dengan variabel yang sedang diteliti (Poerwandari 1998 \& Silalahi, 2003). Jenis metode kualitatif yang digunakan, yaitu studi kasus. Penggunaan studi kasus berguna untuk menguraikan dan menjelaskan secara komperhensif mengenai aspek dari individu, kelompok, organisasi, program atau situasi sosial serta dapat digunakan dalam konteks penelitian dengan lingkup yang terbatas (Silalahi, 2003). Bahasan mengenai dimensi pembentuk iklim organisasi sangat cocok jika ditelisik dengan menggunakan pendekatan kualitatif jenis studi kasus karena terjadi pada lingkup yang terbatas. Artinya, meski iklim organisasi terjadi di semua organisasi, namun, iklim yang terjadi akan berbeda termasuk iklim organisasi yang terbentuk di perusahaan manufaktur karoseri di Surabaya.

Iklim organisasi dapat diketahui dengan menjaring informasi dari persepsi seluruh stakeholder dari perusahaan yang sudah berinteraksi minimal satu tahun (Wirawan, 2008). Sehingga, data primer dalam penelitian ini diperoleh dari wawancara dengan perwakilan manajemen dan karyawan perusahaan manufaktur karoseri di Surabaya. Sedangkan data sekunder dalam penelitian ini diperoleh dari data kajian teori, artikel dan jurnal penelitian yang relevan dengan topik kajian.

Pemilihan informan dalam penelitian ini pun didasarkan pada kriteria tertentu, yaitu anggota organisasi perusahaan manufaktur karoseri PT. Karoseri SUS yang terdiri dari pihak manajerial, pihak karyawan, serta pihak luar yang berinteraksi dengan perusahaan selama lebih dari satu tahun. Informan diperoleh dengan menggunakan metode sampling purposive yang didasarkan pada konstruk operasional variabel yang digunakan sehingga informan sungguh mewakili variabel yang dikaji (Poerwandari, 1998). Teknis pengambilan sampel pada penelitian ini, yaitu melalui pengundian sehingga semua anggota organisasi yang memiliki karakteristik yang sesuai mendapatkan kesempatan yang sama. Nama informan yang sudah dikelompokkan sesuai karakteristik penelitian kemudian diberi penomoran kemudian diundi. Hasil undian itulah yang menjadi informan dalam penelitian ini (Silalahi, 2003)

\section{B. Identifikasi dan Operasionalisasi Variabel}

Variabel dan definisi operasional yang digunakan dalam penelitian ini adalah iklim organisasi yang merupakan persepsi seluruh anggota organisasi perusahaan manufaktur karoseri PT. Karoseri SUS tentang situasi kerjanya.

\section{Teknik Analisis Data}

Teknik analisis data yang digunakan, yaitu inductive thematic analysis yang terdiri dari 3 tahap, yaitu tahap koding. Pada tahap ini, kata-kata kunci dari transkrip verbatim yang relevan dengan pertanyaan penelitian akan ditandai. Kata-kata kunci tersebut diintepretasi oleh peneliti sehingga menghasilkan gagasan atau ide.

Tahap kedua, yaitu tahap kategorisasi, dimana gagasan atau ide hasil intepretasi sebelumnya dikelompokkan berdasarkan satu kategori atau tema yang sama per informan. Kategorisasi ini kemudian dikonfirmasi kepada para informan sebagai salah satu bentuk pertanggungjawaban dan validasi data (Poerwandari, 1998: 117). Hasil kategorisasi semua informan akan digabungkan sehingga membentuk keterkaitan antar tema kategorisasi yang kemudian dilaporkan sebagai temuan penelitian.

\section{HASIL DAN PEMBAHASAN}

\section{A. Hasil penelitian}

Peneliti melakukan wawancara mendalam terhadap 6 informan dengan hasil sebagai berikut:

Tabel 1. Kategorisasi Informan E

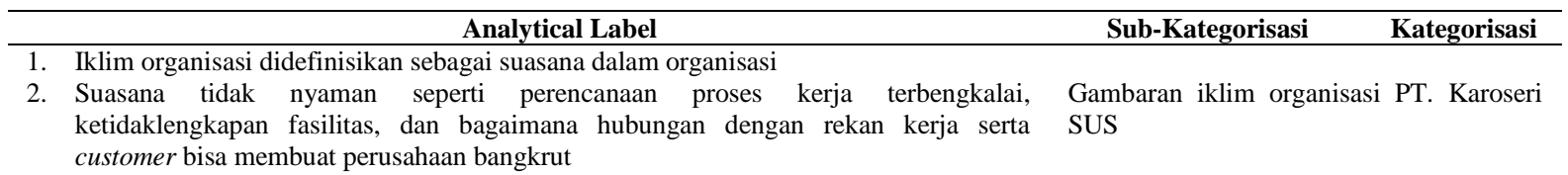


3. Tingkat kesalahan belum bisa diidentifikasi seberapa banyak karena belum optimalnya sistem perusahaan

4. Kesalahan kerja terkait dengan hal teknis seperti penginputan data

5. Pembagian tugas antar karyawan kurang jelas

6. Standar dan prosedur kerja adalah hal mutlak yang harus dikuasai karyawan

7. Prosedur kerja belum lengkap dan masih dibenahi

8. Belum ada pakem yang tetap dalam proses kerja terutama pada bagian administrasi

9. Ada perubahan dalam pembenahan sisdur kerja meskipun belum optimal

10. Tidak ada penilaian kinerja yang terstandarisasi

11. Timbal balik perusahaan lewat komisi terhadap kinerja karyawan

12. Direktur memegang kendali dalam pengambilan keputusan

13. Produksi yang meningkat ditanggulangi dengan penerapan sistem pekerja borongan

14. Hubungan dengan rekan kerja yang baik dapat mendukung proses kerja

15. Hubungan antara atasan dan bawahan baik-baik saja

16. Hubungan baik dengan customer dapat menciptakan repeat order

17. Peran marketing yang mampu membangun hubungan baik dengan customer sehingga bisa terjadi repeat order

18. Bentuk pelayanan terhadap customer, yaitu mempertimbangkan harga yang kompetitif, cara pembayaran, dan chit-chat

19. Ketersediaan bahan yang mendukung pengembangan perusahaan karoseri

20. Ketersediaan fasilitas terutama seperti kesehatan dan kesalamatan kerja membuat suasana kerja lebih nyaman

21. Peralatan untuk keamanan dan keselamatan kerja belum diperhatikan oleh manajemen.

22. Budaya hutang terbentuk karena sering pinjam-pinjam untuk membantu karyawan

23. Payroll adalah solusi untuk budaya hutang

Tabel 2. Kategorisasi Informan J

\section{Analytical Label}

1. Suasana kerja di PT. Karoseri SUS kurang menyenangkan

2. Tipe anggota motivator dan provokator berperan dalam kemajuan atau kemunduran perusahan.

3. SDM Menjadi penggerak jalannya perusahaan

4. Semua data belum terdokumentasi

5. Pembagian tugas tidak jelas serta prosedur membingungkan

6. Dampak ketidakjelasan prosedur kerja menyebabkan keadaan tidak menentu

7. Tanggung jawab borongan rendah karena ketidakjelasan prosedur kerja

8. Tolak ukur produktivitas dan penilaian kerja mengacu pada target kerja

9. Alur birokrasi secara umum yaitu dari top management ke middle management, kemudian ke low management

10. Sistem birokrasi disfungsional

11. Penerapan sistem kepercayaan membuat birokrasi tidak berjalan

12. Komunikasi tertutup dari bawahan terhadap atasan dan disfungsional

13. Penghargaan direksi dan dukungan terhadap karyawan rendah

14. Karyawan menjadi apatis terhadap perintah direksi

15. Karateristik pemimpin keras

16. Direksi punya standar kerja yang tinggi

17. Keintiman dan kebersamaan dalam hubungan antar rekan kerja rendah

18. Hubungan antarteman sekerja terbentuk grouping yang berimbas pada proses kerja individual

19. Peran konsultan untuk mengatasi kendala di PT. Karoseri SUS, yaitu menjadi jembatan antara direksi dengan karyawan

20. Pelayanan berupa pemberian fasilitas dari klien mendukung kinerja konsultan

21. Karakteristik direksi yang keras adalah salah satu kesulitan konsultan untuk mengadakan perubahan

22. Ketersediaan fasilitas mendukung perubahan di organisasi

23. Lingkungan kerja perlu pembenahan termasuk pembenahan secara fisik

24. Penggunaan fasilitas dapat mempermudah pekerjaan

25. Fasilitas safety kurang

26. Terbentuk asas 'Asal Bapak Senang'

27. Budaya meeting muncul tanpa ada tindakan nyata terhadap hasil meeting

28. Esensi sebenarnya dari meeting hilang karena tidak adanya action plan

$\begin{array}{ll}\begin{array}{l}\text { Standar dan prosedur } \\ \text { kerja }\end{array} & \\ & \\ & \text { Penerapan } \\ & \text { sistem } \\ & \text { manajemen }\end{array}$

Sistem imbalan

Pihak pengambil

keputusan

Gambaran Manajemen

konflik

Hubungan antar anggota

dalam organisasi

$\begin{array}{rr}\text { Hubungan } & \text { antara } \\ \text { organisasi dengan }\end{array}$

customer

Alokasi sumber daya

Fasilitas dan proses kerja

Pola kebiasaan dalam organisasi

manajemen
Sub-Kategorisasi

Kategorisasi

Gambaran iklim organisasi PT. Karoseri SUS

Unsur pembentuk

Penerapan prosedur kerja

Penerapan standar kerja

Penerapan sistem

birokrasi

Hubungan antara atasan dengan bawahan

Hubungan antar rekan kerja

Peranan konsultan

Sarana dan prasarana Lingkungan yang disediakan fisik

Pola kebiasaan dalam organisasi PT. Karoseri SUS 
Tabel 3. Kategorisasi Informan R

\begin{tabular}{|c|c|c|}
\hline Analytical Label & Sub Kategorisasi & Kategorisasi \\
\hline Pembuatan prosedur kerja perlu dibuat untuk pembenahan sistem manajemen & & \\
\hline 2. Direksi tidak komit terhadap prosedur kerja yang diterapkan & & \\
\hline 3. Pimpinan perusahaan melanggar prosedur kerja & & \\
\hline 4. Karyawan merasa apatis terhadap prosedur kerja & & \\
\hline 5. Karyawan lalai terhadap prosedur kerja khususnya terkait waktu kerja & & \\
\hline 6. Karyawan tidak taat terhadap prosedur dengan mengatur waktu kerja seenaknya & Standar dan Prosedur & \\
\hline 7. Perencanaan sumber daya manusia tidak ada & & \\
\hline $\begin{array}{l}\text { 8. Perusahaan menjadi tergantung kepada } 1 \text { orang Deskripsi kerja merambat kemana- } \\
\text { mana }\end{array}$ & & \\
\hline 9. Pemerataan deskripsi kerja tidak merata & & \\
\hline 10. Jenjang karir terbatas & & \\
\hline 11. Lembur adalah loyalitas & & \\
\hline $\begin{array}{l}\text { 12. Karyawan merasa gaji yang diterima tidak setimpal dengan pekerjaan yang } \\
\text { dikerjakan }\end{array}$ & & \\
\hline $\begin{array}{l}\text { 13. Karyawan merasa gaji yang diberikan tidak seimbang dibandingkan dengan } \\
\text { karyawan lain }\end{array}$ & Sistem imbalan & \\
\hline 14. Harapan untuk perbaikan kesejahteraan jika ditawari kontrak baru & & \\
\hline 15. Birokrasi yang terjadi adalah dari karyawan langsung ke bos & $\begin{array}{l}\text { Penerapan } \\
\text { birokrasi }\end{array}$ & \\
\hline 16. Atasan cuek terhadap informasi karyawan tentang dampak negatif seringnya rapat & & \\
\hline 17. Direksi tidak merepson aspirasi karyawan & & \\
\hline 18. Potensi terjadi konflik karena pimpinan tidak perhatian pada karyawan & & \\
\hline 19. Gambaran pimpinan PT. X memiliki karakteristik keras & & \\
\hline 20. Pimpinan keras kepala terhadap pendapatnya & & \\
\hline 21. Adanya pengembangan karyawan oleh atasan dalam proses kerja & & \\
\hline 22. Karyawan bebas membuat keputusan sendiri sejauh tidak bermasalah fatal & & \\
\hline $\begin{array}{l}\text { 23. Karyawan diberikan kebebasan untuk menentukan sendiri tindakan dalam proses } \\
\text { kerja }\end{array}$ & $\begin{array}{l}\text { Hubungan antara } \\
\text { bawahan dengan atasan }\end{array}$ & \\
\hline 24. Kehangatan dan keintiman hubungan rekan kerja kurang & Hubungan antara rekan & \\
\hline 25. Kendala yang terjadi seperti salah paham antar rekan kerja dalam proses produksi & kerja & \\
\hline 26. Peranan konsultan di PT. Karoseri SUS kurang optimal & Hubungan dengan pihak & \\
\hline 27. Pekerjaan yang tertunda berimbas pada protes customer & luar & \\
\hline 28. Fasilitas kurang lengkap & & Lingkungan \\
\hline 29. Kekurangan fasilitas menghambat proses kerja & Fasilitas pendukung & fisik \\
\hline 30. Orang yang ngutang banyak & & Pola \\
\hline 31. Sering diadakan rapat namun tidak tepat guna & Kebiasaan-kebiasaan & kebiasaan \\
\hline 32. Rapat membuat proses kerja tertunda & dalam organisasi & $\begin{array}{l}\text { dalam } \\
\text { organisasi }\end{array}$ \\
\hline
\end{tabular}

Tabel 4. Kategorisasi Informan A

\begin{tabular}{lll}
\hline & \multicolumn{1}{c}{ Analytical Label } & \multicolumn{1}{c}{ Sub Kategorisasi } \\
\hline 1. & Sistem produksi karoseri masih dalam tahap perbaikan & Prosedur dan standar \\
2. & Konsekuensi dari pembenahan sistem manajemen terhadap produksi & kerja \\
3. & Ada target kerja di PT. Karoseri SUS & Sistem imbalan \\
4. & Tingkat kecukupan karyawan terhadap sistem imbalan berbeda-beda & Sarana dan prasarana \\
5. Penyediaan fasilitas masih perlu dibenahi & pendukung \\
6. Perlu penyediaan alat bantu proses produksi & Hubungan antar anggota Lingkungan \\
7. & Karakteristik orang tergantung dari tempat pekerjaanya & dalam organisasi \\
8. & Potensi konflik jika banyak kesalahpahaman & sosial \\
\hline
\end{tabular}

Tabel.5. Kategorisasi Informan M

\begin{tabular}{|c|c|c|c|}
\hline \multicolumn{2}{|r|}{ Analytical Label } & Sub Kategorisasi & Kategorisasi \\
\hline 1. & Prosedur kerja kurang jelas dan sering berubah & Prosedur kerja & \\
\hline 2. & $\begin{array}{l}\text { Sistem manajemen membingungkan } \\
\text { kepemimpinan ganda }\end{array}$ & Pola kepimpinan & \\
\hline 3. & Sarana dan prasarana masih perlu ditambahkan & Kelengkapan fasilitas & \\
\hline $\begin{array}{l}4 . \\
5 .\end{array}$ & $\begin{array}{l}\text { Keselamatan kerja masih perlu dibenahi } \\
\text { Tidak semua karyawan menggunakan } \\
\text { keselamatan kerja yang disediakan }\end{array}$ & $\begin{array}{l}\text { Fasilitas kesehatan dan } \\
\text { keselamatan kerja }\end{array}$ & \\
\hline 6. & Hubungan dengan rekan kerja tergantung tempat kerjanya & Lingkungan sosial & \\
\hline 7. & Meeting sering diadakan dan menghambat proses kerja & Pola kebiasaan meeting & Pola kebiasaan perilaku organisasi \\
\hline
\end{tabular}


Tabel 6. Kategorisasi Informan J

\begin{tabular}{|c|c|c|}
\hline Analytical Label & Sub Kategorisasi & Kategorisasi \\
\hline Produksi naik secara drastis & Produksi & \\
\hline 2. Gambaran kejelasan dan pembagian deksripsi kerja & Prosedur kerja & \\
\hline 3. Pemberian bonus tidak menentu & Sistem imbalan & \\
\hline Terbentuk grouping yang bekerja secara individual & Hubungan antar rekan kerja & \\
\hline 6. Grouping tidak terlihat secara kasat mata & & \\
\hline 9. Peran konsultan dominan di kantor & & \\
\hline 10. Fasilitas belum lengkap dan mengganggu proses kerja & Fasilitas pendukung kerja & Lingkungan fisik \\
\hline 11. Intensitas rapat masih sering & Kehiasaan meetino & Pola kebiasaan \\
\hline 12. Rapat membuat pekerjaan terhambat & Kebiasaan meetıng & organisasi \\
\hline
\end{tabular}

Berdasarkan hasil penelitian di atas, maka keterkaitan antar tema dimensi pembentuk iklim organisasi pada Perusahaan PT. Karoseri SUS digambarkan melalui Gambar 1 dibawah ini.

\section{Penerapan Sistem Manajemen: \\ 1. Standar dan prosedur kerja \\ 2. Sistem imbalan \\ 3. Sistem birokrasi}

\section{Lingkungan Sosial:}

1. Hubungan antara atasan dan bawahan

2. Hubungan antar rekan kerja

3. Hubungan antara organisasi dengan pihak luar

Lingkungan Fisik:

Sarana \& Prasarana serta fasilitas pendukung proses kerja

Pola Kebiasaan dalam

Organisasi:

1. Rapat

2. Hutang pribadi karyawan

Gambar 1. Keterkaitan Antar Tema Dimensi Pembentuk Iklim Organisasi PT. Karoseri SUS.

\section{B. Pembahasan}

Iklim organisasi di dalam PT. Karoseri SUS yang dimaknai oleh para informan senada dengan Wirawan (2008), Sari (2009) dan Muthukumar \& Guru (2016) sebagai suasana kerja dalam perusahaan yang dialami karyawan. Adapun suasana kerja yang dimaksud seperti kejelasan tujuan organisasi, ruang kerja yang menyenangkan, rasa aman dalam bekerja, sarana dan prasarana yang mendukung, kejelasan karir dan tugas serta tanggung jawab, hubungan antar anggota termasuk dengan pihak luar yang terjadi di organisasi. Gambaran para informan mengenai konsep suasana kerja dan iklim organiasi di PT. Karosersi SUS Surabaya relevan dengan 
hasil preliminary-research yang ditemukan peneliti sebelumnya. Secara umum gambaran iklim organisasi di PT. Karoseri SUS kurang menyenangkan dan ternyata membentuk iklim organisasi yang kurang kondusif.

Muthukumar \& Guru (2016), Yadav, et al (2016), Dewi \& Prasetyo (2017), Berberoglu (2018) menjabarkan bahwa iklim organisasi dapat membawa dampak yang besar bagi pembentukan sikap dan perilaku serta kinerja karyawan terhadap organisasi. Iklim organisasi yang kurang kondusif di PT. Karoseri SUS sudah menimbulkan berbagai macam dampak negatif seperti terhambatnya komunikasi antar anggota, terbentuk kubu-kubu, dan belum maksimalnya pekerjaan karyawan. Para informan menambahkan bahwa iklim organisasi yang tidak nyaman dapat membuat karyawan tidak bekerja dengan maksimal. Pekerjaan yang tidak maksimal ini pun berpengaruh terhadap proses produksi dan ketika hal ini dibiarkan, maka akan berpotensi pada stabilitas usaha PT. Karoseri SUS yang bisa saja berujung pada kebangkrutan (Stinger, 2002; Wirawan, 2008; Asfrizal \& Kasmiruddin, 2013; Li \& Mahadevan, 2017, dan Berberoglu, 2018). Adapun suasana kerja yang dimaksud, yaitu kelengkapan fasilitas, hubungan antar rekan kerja dan customer.

Iklim organisasi di PT. Karoseri SUS dibentuk oleh empat dimensi. Masing-masing dimensi memiliki subkategori tersendiri. Dimensi pembentuk yang pertama, yaitu penerapan sistem manajemen. Sistem manajemen diartikan sebagai alur birokrasi, standar dan prosedur dari seluruh proses kerja yang ada di PT. Karoseri SUS. Penerapan sistem manajemen yang jelas, transparan, akuntabel, dan operasional dapat meningkatkan kinerja individu yang mendorong optimalnya produktivitas organisasi (Wirawan, 2008 dan Sari, 2009) Sebagai dimensi pembentuk iklim organisasi di PT. Karoseri SUS, sistem manajemen yang perlu diterapkan berkaitan dengan beberapa hal, yaitu (1) prosedur dan standar kerja; (2) sistem imbalan; dan (3) sistem birokrasi.

Idealnya, prosedur kerja yang meliputi tata tertib, peraturan, alur kerja harus diperjelas oleh pihak organisasi. Anggota dan dalam hal ini para karyawan PT. Karoseri SUS harus mampu memahami apa dan bagaimana mereka harus melakukan tugasnya. Tetapi senyatanya, semua data termasuk prosedur kerja tersebut belum terdokumentasi. Prosedur kerjanya pun seringkali berubah-ubah. Dampaknya, para karyawan tersebut mengalami kebingungan akibat dari pembagian tugas yang tidak jelas. Selain itu, tata tertib dan prosedur yang sudah dibuat ini seringkali dilanggar oleh para pimpinannya sendiri. Seharusnya, para pimpinan atau atasan menjadi role model bagi para karyawan. Akibat dari ketidakjelasan prosedur kerja, serta atasan tidak mampu menjadi contoh yang baik bagi anggotanya berimbas pada menurunnya rasa tanggung jawab dari para karyawan seperti keterlambatan kerja, tingginya kesalahan dalam bekerja, serta banyak keluhan yang terjadi (Stinger, 2002; Idrus, 2006; Luthans, 2006; Wirawan, 2008; dan Bahrami, et al, 2016). Bahkan, para informan menyatakan bahwa ketika atasan mengeluarkan perintah baru, para karyawan cenderung akan menghiraukannya. Hal inilah yang mendorong terciptanya suasana kerja yang kurang menyenangkan selama proses kerja di PT. Karoseri SUS.

Standar kerja berkaitan dengan target apa yang harus dicapai oleh para anggota dan bagaimana untuk mengukur kinerja tersebut. Idealnya, semua divisi di suatu organisasi harus memiliki standar dan target kerja yang terukur. Stinger (2002) menyatakan bahwa jika suatu organisasi memiliki struktur dan standard kerja yang tinggi, maka anggota organisasi tersebut merasa bahwa pekerjaan mereka terdefinisikan dengan baik sehingga memacu pengoptimalan kinerja. Sehingga, indikator keberhasilan di tiap jabatan pun perlu diperjelas agar para pemangkunya mengetahui apa dan bagaimana harus mencapainya. Regulasi dan standar kerja sangat perlu dibuat, diperjelas dan dikontrol oleh pihak organisasi sehingga memfasilitasi terciptanya inovasi, kreativitas, dan keterbukaan antar anggota organisasi (Björkdahl \& Börjesson, 2011; dan Berberoglu, 2018). Selama ini, hampir semua divisi PT. Karoseri SUS tidak pernah diberikan target oleh para pimpinannya. Divisi sales dan marketing dan produksi memang sudah diberikan target, tetapi tidak ada sistem monitoringnya. Sehingga, tidak ada konsekuensi jika terjadi ketidaktercapaian target. Keterlambatan penyelesaian tugas, hasil kerja yang kurang sesuai standard, serta kesalahan kerja pun cukup sering terjadi di PT. Karoseri SUS. Selain itu, delegasi tugas pun sering tidak sesuai dengan struktur jabatan yang ada. Jika hal ini dibiarkan maka dapat berimbas pada menurunnya kinerja organisasi, munculnya ketidakpuasan customer, dan berpotensi meruginya perusahaan (Muthukumar \& Guru, 2016; Li \& Mahadevan, 2017).

Salah satu prosedur dan standard kerja yang harus dimiliki oleh perusahaan, yaitu dokumen analisis jabatan. Berdasarkan hasil wawancara yang telah dilakukan kepada pihak personalia divisi Human Resources department (HRD), pihak perusahaan tidak memiliki dokumen analisis jabatan. Semenjak perusahaan berdiri hingga sekarang, dokumen analisis jabatan tidak dibuat oleh Divisi HRD karena tiga hal, yaitu (1) Divisi HRD adalah divisi baru sehingga segala sesuatu mengenai pengembangan sumber daya manusia termasuk pembuatan analisis jabatan belum dilakukan, (2) ketidaktahuan Divisi HRD mengenai mekanisme pembuatan analisis jabatan, (3) fokus Divisi HRD belum pada pembenahan sistem pengembangan organisasi / organizational 
system development melainkan pada administrasi karyawan seperti pembenahan sistem database karyawan (identitas dan data administratif lainnya). Dampak dari tidak adanya analisis jabatan yang terdokumentasi ini membuat penumpukan pekerjaan dan silang jabatan antar divisi dan bagian (overload \& overlapping job). Seharusnya, semua karyawan di dalam suatu organisasi harus memahami jabatannya secara utuh serta memiliki dokumen analisis jabatan yang menjadi panduan bagi mereka untuk melakukan suatu pekerjaan (Mondy, 2010 dan Suthar, 2014). Tetapi, disisi lain, ketika suatu organisasi memiliki ketidakjelasan pekerjaan, maka bisa berdampak pada penurunan kualitas kerja, memunculkan ketidakpuasan kerja, serta berdampak pada peningkatan stress kerja (Snowden \& Hardy, 2012; Bonin, 2013; dan Strassnig, et al, 2015). Dampak yang lebih panjang, yaitu iklim di suatu organisasi termasuk di PT. Karoseri SUS pun menjadi tidak kondusif, seperti yang ditunjukkan melalui gejala-gejala protes karyawan karena ketidakjelasan tugas, keterlambatan penyelesaian tugas karena harus mengerjakan pekerjaan yang bukan menjadi tanggung jawabnya, serta kebingungan dari Divisi HRD untuk membuat penilaian kinerja karena tidak adanya patokan pekerjaan mana yang harus dinilai.

Sistem imbalan memiliki pengaruh besar terhadap terciptanya iklim kerja yang baik di dalam organisasi (Sari, 2009). Di PT. Karoseri SUS terdapat dua sistem imbalan yang diberlakukan, yaitu komisi dan gaji pokok. Komisi diberikan kepada pihak marketing karena kinerjanya mampu meningkatkan permintaan produksi. Sedangkan gaji pokok diberikan kepada semua karyawan. Iklim organisasi menjadi kurang kondusif juga dipengaruhi oleh sub-kategori ini. Permasalahan yang muncul adalah gaji yang diberikan dirasa tidak cocok jika dibandingkan dengan beban pekerjaan yang dikerjakan. Staf production planning inventory control (PPIC) yang menjadi salah satu informan dalam penelitian ini menyatakan bahwa permintaan produksi semakin banyak, namun tidak ada penambahan tenaga kerja sehingga berakibat terjadinya lembur kerja. Akan tetapi, pihak manajemen tidak memberikan kompensasi apapun dan mengganggap hal tersebut sebagai bentuk loyalitas. Perasaan tidak adil pun muncul dari diri para informan, dimana ada karyawan yang memiliki deskripsi kerja yang sangat banyak, yaitu dari proses awal penerimaan permintaan produksi hingga produksi diberikan kepada customer, namun memiliki gaji yang hampir sama dengan pemangku jabatan yang deskripsi kerjanya lebih sedikit.

Hal senada diungkapkan oleh Kepala Produksi dan Penyelia (setingkat level supervisor) produksi yang diwawancara pada kesempatan yang berbeda, dimana mereka menyatakan bahwa pemberian bonus terhadap suatu pencapaian prestasi pun tidak dilakukan oleh pihak manajemen secara konsisten. Dampak dari inkonsistensi masalah imbalan ini bisa saja berpengaruh terhadap keterlibatan kerja dan komitmen dari para karyawan, khususnya di bagian produksi. Gejala seperti enggan untuk memberikan pendapat perbaikan kinerja sudah terlihat di organisasi ini dan menjadi tanda bahwa keterlibatan kerja para karyawan cenderung minim (Robbin \& Judge, 2008). Dampak ketika karyawan menjadi tidak merasa terlibat di dalam pekerjaannya, yaitu karyawan menjadi tidak komit dengan kinerjanya (Luthans, 2006), berakibat pada kinerja organisasi menjadi tidak maksimal dan berujung pada kegagalan pencapaian tujuan organisasi (Robbin \& Judge, 2008). Hal ini menyebabkan iklim organisasi yang tidak kondusif pun bisa tercipta (Luthans, 2006; Robbin \& Judge, 2008; dan Novarinda \& Iqbal, 2017).

Berberoglu (2018) menyatakan bahwa iklim organisasi yang kondusif hanya akan tercipta jika para karyawan mampu mempersepsikan bahwa perusahaan adil terhadap mereka. Di satu sisi, prinsip kewajaran dan keadilan dalam sistem imbalan bukan berarti berapapun gaji yang diminta karyawan harus dipenuhi oleh atasan atau owner. Koys dan DeCotiis (dalam Wirawan, 2008) menyatakan bahwa permintaan karyawan harus tetap disesuaikan dengan beban kerja, tanggung jawab, serta perannya. Namun, karena iklim organisasi terbentuk pula dari persepsi anggota terkait praktik organisasi yang adil, wajar, dan tidak sewenang-wenang, maka, hal equality \& fairness dalam hal imbalan atau rewards perlu diperjelas. Hal ini pun didukung melalui penjelasan dari para karyawan di bagian staf produksi yang diwawancara oleh peneliti dalam proses diskusi kelompok (groud discussion). Mereka menyatakan akan lebih baik jika pihak perusahaan merancang suatu sistem imbalan sehingga beban kerja dan apa yang mereka terima bisa seimbang. Kejelasan dalam sistem imbalan ini pun perlu diterapkan secara konsisten oleh para pimpinan.

PT. Karoseri SUS sudah memiliki struktur organisasi yang cukup jelas. Artinya, masing-masing karyawan sudah memiliki nama jabatan masing-masing dan sudah mengetahui tugas-tugasnya meski belum terdokumentasi di dalam sebuah dokumen analisis jabatan. Sehingga, seharusnya alur birokrasi dan rantai komando disesuaikan dengan struktur yang ada. Idealnya, dalam konsep manajemen, birokrasi dalam perusahaan terbagi menjadi tiga bagian, yaitu top-management, middle management, dan low management. Topmanagement terdiri dari atasan dalam hal ini direksi, middle management terdiri dari level supervisor hingga manajerial, dan low management semua level di bawah supervisor. Pada umumnya alur birokrasi yang dibentuk 
adalah middle management bertanggung jawab terhadap top management lalu middle management mengontrol low management. (Robbins, DeCenzo, Coulter, Anderson, 2017).

Berbanding terbalik dengan sistem birokrasi di PT. Karoseri SUS dimana sistem birokrasi tersebut disfungsional. Tidak berfungsinya sistem birokrasi ini disebabkan karena atasan dalam hal ini top management melakukan pengontrolan secara langsung terhadap low management. Pada akhirnya, middle management tidak berfungsi dan merasa bahwa struktur tersebut dilangkahi. Demikian pula dari low management pada akhirnya tanpa mempertanggungjawabkan kerjanya terhadap middle management melainkan langsung ke top maangement. Perasaan bahwa perannya tidak dianggap oleh para top management diungkapkan para supervisor di bagian marketing. Supervisor marketing menyatakan bahwa top management bertanya mengenai kinerja omzet perusahaan langsung kepada para staf marketing, dan tidak melalunya. Padahal, kontrol dan pemantauan terhadap kinerja staf marketing sudah dilakukannya. Kondisi yang sama juga dirasakan oleh manajer keuangan dan akuntansi, dimana ketika top management membutuhkan laporan keuangan, maka langsung ditanyakan ke staf yang mengerjakan, dan bukan melalui manajer. Perasaan tidak dianggap ini pun berimbas pada Keinginan untuk terlibat dalam pekerjaan serta komitmen kerja yang menjadi melemah dan bertindak asal-asalan dalam bekerja (Robbin \& Judge, 2008; dan Novarinda \& Iqbal, 2017). Hal ini pun ditunjukkan melalui intensitas keterlambatan yang tinggi, tidak tercapainya target kerja, dan bahkan keluhan berupa tindak demontrasi dari pihak middle-management terhadap divisi human resources and development (Stinger, 2002; Idrus, 2006; Wirawan, 2008; Robbins, et al 2017; Berberoglu, 2018).

Situasi dan kondisi terhadap penerapan sistem manajemen PT. Karoseri SUS terkesan tidak kondusif yang ditunjukkan ketidakjelasan prosedur dan standar kerja, sistem imbalan yang dirasa karyawan tidak adil, serta alur birokrasi yang menjadi disfungsional.

Dimensi yang kedua, yaitu berkaitan dengan lingkungan sosial yang difokuskan pada interaksi antar seluruh anggota organisasi termasuk berbagai pihak yang rutin berdinamika dengan PT. Karoseri SUS. Suatu iklim organisasi yang kondusif dapat tercipta ketika adanya kerja sama yang baik pula antar karyawan, karyawan dengan manajer, manajer dengan top management (Yani, Tunas, Entang, 2017). Dimensi lingkungan sosial ini dibentuk oleh beberapa sub-kategori, yaitu (1) hubungan antara atasan dan bawahan; (2) hubungan antar rekan kerja; dan (3) hubungan antara organisasi dengan pihak luar:

Atasan di PT. Karoseri SUS meliputi pemilik perusahaan / owner yang terdiri dari direktur utama, kedua anak dari direktur utama sebagai manajer operasional dan manajer penjualan, serta istri dari direktur utama sebagai manajer keuangan-HRGA (Human Resources and General Affairs). Sedangkan, bawahan yang dimaksud, yaitu semua anggota organisasi non-owner.

Menurut informasi dari para manajer, hubungan antara atasan dan karyawan berada dalam kategori berhubungan baik. Manajer meyakini selama tidak ada demo atau protes berlebihan daripada karyawan, berarti hubungan antara karyawan dengan atasan baik-baik saja. Namun, berdasarkan hasil diskusi dengan para karyawan di bidang ekspor impor dan teknologi informasi, hubungan antara atasan dan karyawan kurang kondusif karena tidak adanya pengakuan, serta sikap cuek dari atasan. Para karyawan merasa bahwa pekerjaan telah dilakukan secara optimal, namun para manajer selalu merasa tidak puas terhadap hasil tersebut. Pihak atasan pun terkesan cuek dan tidak merespon keluhan yang diungkapkan oleh para karyawan terhadap proses kerja sehingga memunculkan rasa takut dan putus asa karena kinerjanya tidak bisa memuaskan pihak atasan. Selain itu, keluhan dari para karyawan yang tidak direspon oleh pihak atasan membuat karyawan merasa tidak dihargai. Pada akhirnya menimbulkan berbagai perasaan negatif seperti rasa takut, putus asa, dan perasaan tidak dihargai. Perasaan negatif menyebabkan karyawan merasa terisolasi dan tersisih sendiri lalu kemudian membentuk perasaan apatis. Bentuk nyata dari perasaan apatis ini ditunjukkan karyawan dengan dua sikap yang berbeda, yaitu tidak mematuhi ataupun tidak menghiraukan perintah atasan serta karyawan bekerja berdasarkan prinsip 'asal bapak senang', yang artinya karyawan tidak melakukan pekerjaan menurut kemampuan terbaiknya, namun hanya sampai pada tingkat, yang penting atasan puas dan senang maka pekerjaan itu sudah selesai (Stinger, 2002; Wirawan, 2008; Dewi \& Prasetyo, 2017; dan Li \& Mahadevan, 2017).

Meski mempersepsikan hubungannya dengan atasan menjadi kurang kondusif, para karyawan cukup mengapresiasi pihak atasan khususnya terkait kesempatan untuk mengembangkan diri. Adanya kesempatan untuk terlibat di seluruh proses kerja dari awal hingga akhir, keleluasaan untuk menentukan sikap kerja, serta pengambilan keputusan dibawah supervisi atasan merupakan langkah konkrit dari perusahaan untuk memberikan otonomi kepada para karyawannya. Sebagai salah satu penentu iklim organisasi, akan lebih baik jika pihak manajemen secara konsisten memberikan otonomi kepada karyawan. Otonomi ini mampu 
meningkatkan rasa tanggung jawab serta inisiatif karyawan dalam bekerja (Idrus, 2006; Ekvall, Koys dan DeCotiis dalam Wirawan, 2008; Yani, Tunas \& Entang, 2017; dan Berberoglu, 2018).

Iklim organisasi dipengaruhi oleh kesadaran dan keinginan dari pihak manajemen untuk berubah. Implementasi nyata dari strategi perubahan organisasi oleh manajemen dapat mendukung naiknya tingkat kepercayaan karyawan terhadap pihak manajerial (Björkdahl \& Börjesson, 2011). Pihak manajemen berperan penting dalam upaya pembentukan iklim yang positif dan yang diinginkan oleh para karyawan sehingga rasa tanggung jawab, keterikatan emosional, dan hasrat untuk mencapai tujuan organisasi dapat terwujud (Stinger, 2002). Dalam mengimplementasikannya, iklim organisasi harus diciptakan dari diri para manajer itu sendiri, dan dalam hal ini para owner PT. Karoseri SUS yang berperan sebagai pimpinan tertinggi dalam operasional perusahaan. Para owner ini harus mampu fokus dan memahami secara detil mengenai tujuan dari organisasi atau organizational goals, serta memiliki komitmen untuk mencapainya. Hal tersebut harus tercermin dalam sikap mereka sehari-hari, dalam setiap keputusan yang diambil, kebijakan yang dibuat, dan prosedur yang diberlakukan. Perilaku, perkataan, perbuatan dan pemikiran yang baik dan konsisten dari para pihak manajerial akan menjadi contoh bagi para karyawan dalam proses kerjanya sehari-hari. Para manajer harus menjadi role model bagi para karyawannya (Wirawan, 2008; Permarupan et al, 2013; Bahrami et al, 2016; Sayoga, 2018).

Para karyawan harus benar-benar diperhatikan oleh para owner PT. Karoseri SUS terutama mengenai kesejahteraan dan kejelasannya dalam bekerja. Hal ini akan mendorong terciptanya passionate employee atau karyawan yang bergairah sehingga nantinya akan mendorong terciptanya komitmen organisasi. Anggota organisasi yang berkomit dengan organisasinya akan puas dengan organisasinya serta mampu mengimplementasikan kontribusi kerja yang efektif dan efisien dalam upaya pencapaian tujuan organisasi (Bahrami et al, 2016; Muthukumar \& Guru, 2016; Li \& Mahadevan, 2017). Para pimpinan di PT. Karoseri SUS harus meningkatkan kompetensi kepemimpinan mereka mengingat pemimpin organisasi adalah salah satu aspek penting yang berpengaruh terhadap terciptanya iklim organisasi yang kondusif (Yani, Tunas, \& Entang, 2017; dan Sayoga, 2018).

Interaksi yang terbangun di dalam organisasi pada setiap divisinya membentuk kelompok-kelompok tertentu I grouping. Di PT. Karoseri SUS ini sendiri, grouping tersebut memunculkan tiga kelompok yang disebut kelompok 'orang atas', yaitu semua karyawan yang berkantor di lantai 2, dan kelompok 'orang bawah', yaitu semua karyawan yang berkantor di lantai 1, serta kelompok 'produksi dan gudang', yaitu semua karyawan yang berada di pabrik bagian produksi dan gudang. Menurut Koys DeCotiis dan Ekvall (dalam Wirawan, 2008), group ini dibentuk dari kebersamaan / cohesion akibat interaksi rutin dan area kerja yang sama sehingga dapat membentuk suatu hubungan yang intim / playfulness.

Dampak positif dari kemunculan grup sebagai bentuk interaksi antar rekan kerja di PT. Karoseri SUS, yaitu interaksi yang terjadi di satu divisi / grup yang sama menjadi dekat, komunikasi menjadi lebih terbuka, dan koordinasi menjadi lebih mudah. Hanya saja, dampak negatif yang muncul, yaitu integrasi antar divisi menjadi kurang optimal, kehangatan, rasa kebersamaan dan keharmonisan antara karyawan di antar divisi menjadi rendah. Rendahnya hubungan antar karyawan ini ditunjukkan dengan penolakan karyawan untuk membantu rekan kerjanya ketika pekerjaan karyawan tersebut sudah selesai, saling menyalahkan ketika terjadi kesalahan kerja, serta sudah pernah berdampak pada konflik terbuka, berupa adu argument antar divisi.

Hubungan antar rekan kerja ini menjadi salah satu penentu iklim organisasi di PT. Karoseri SUS. Kurang hangatnya interaksi dan terbentuknya grup ini membuat suasana kerja menjadi tegang, dan tidak akrab (Idrus, 2006; Luthans, 2006; Wirawan, 2008; Permarupan, et al, 2013; Bahrami, et al, 2016; Li \& Mahadevan, 2017; dan Berberoglu, 2018). Inilah menjadi salah satu penyebab iklim organisasi di perusahaan ini menjadi kurang kondusif.

Wirawan (2008) menyatakan iklim organisasi dapat diidentifikasi dari persepsi dengan pihak luar organisasi. Pihak luar yang diidentifikasi dalam penelitian ini meliputi konsultan dan customer. Salah satu usaha yang dilakukan PT. Karoseri SUS untuk membenahi perusahaannya adalah dengan menggunakan jasa konsultan. Konsultan bertugas untuk menjadi jembatan antara direksi dan karyawan, membenahi sistem manajemen, serta membentuk tim untuk memastikan bahwa perubahan yang akan diadakan tetap akan bertahan. Untuk membangun hubungan baik dengan pihak konsultan, pihak perusahaan juga menyediakan berbagai fasilitas pendukung proses kerja konsultan seperti fasilitas makan siang serta berbagai akses terhadap data perusahaan di bawah supervisi para manajer. Hanya saja, peran konsultan belum efektif. Direktur utama tidak mengaplikasikan semua jasa yang diberikan oleh konsultan, tetapi di sisi lain, kinerja konsultan tersebut dinilai kurang optimal. Selain itu, konsultan tersebut lebih banyak menghabiskan waktu di kantor daripada di pabrik sehingga para karyawan yang berada di lokasi lain kurang bisa merasakan kehadiran konsultan tersebut. Relasi yang kurang dekat antara konsultan dengan divisi lain khususnya di divisi produksi membuat suasana kerja 
menjadi kurang hangat. Pekerjaan dari konsultan dalam upaya pembenahan sistem khususnya di bidang produksi menjadi terhambat karena para karyawan enggan untuk mengaplikasikan hal tersebut. Kurangnya dukungan dari atasan pun membuat progress kerja konsultan menjadi terhambat pula.

Hubungan organisasi dengan pihak lainnya, yaitu customer. Customer menjadi salah satu unsur pembentuk iklim sekaligus pendukung kinerja organisasi. Wirawan (2008) menjabarkan bahwa organisasi harus memperhatikan dan meningkatkan relasi yang baik dengan customer. PT. Karoseri SUS sudah cukup mampu dalam membina dan mempertahankan hubungan dengan para customer melalui berbagai cara, seperti menawarkan harga yang kompetitif, cara pembayaran yang fleksibel, serta mendatangi tempat customer untuk sekedar membicarakan hal-hal ringan. Dalam proses kerja pun pihak perusahaan selalu berusaha untuk menepati perjanjian kerja yang diadakan. Jika pengerjaan produk atau hasil produksi tidak sesuai dengan perjanjian kerja, maka customer akan melakukan komplain berupa permintaan potongan harga. Jika hal ini dibiarkan terus maka customer berpotensi memutuskan hubungan kerja sama dengan PT. Karoseri SUS.

Iklim organisasi tidak hanya terkait hal non-fisik melainkan pula dengan hal fisik (Idrus, 2006). Hal fisik yang dimaksud adalah lingkungan fisik yang berkaitan dengan tempat kerja serta sarana prasarana yang mendukung proses kerja (Wirawan, 2008) dan merupakan dimensi ketiga pembentuk iklim organisasi di PT. Karoseri SUS. Bagi perusahaan karoseri termasuk PT. Karoseri SUS, lingkungan kerja yang kondusif adalah ketika perusahaan mampu menerapkan sistem kerja yang efisien dan efektif serta adanya sarana dan prasarana yang lengkap (Stinger, 2002; Dewi \& Prihatsanti, 2010; Björkdahl \& Börjesson, 2011; Dewi \& Prasetyo, 2017; dan Simamarta, et al, 2017). Ketika karyawan mempersepsikan fasilitas dan tempat kerjanya nyaman, maka akan menciptakan suasana kerja yang nyaman pula. Dengan demikian persepsi karyawan terhadap kenyamanan suasana kerja mampu menciptakan iklim organisasi yang nyaman pula (Wirawan, 2008).

Menurut manajer dari PT. Karoseri SUS, fasilitas dan sarana prasarana yang disediakan sudah cukup mendukung seluruh proses kerja yang ada. Pihak perusahaan sendiri terus melakukan pengembangan dan penambahan fasilitas untuk makin mendukung kinerja dari para anggota. Fasilitas komputer, pendingin udara, serta fasilitas makan siang dan ruangan makan merupakan salah satu penunjang kerja yang disediakan oleh perusahaan. Namun, para karyawan memiliki persepsi lain bahwa tidak semua karyawan difasilitasi oleh perusahaan.

Di dalam dimensi ini, lingkungan fisik dijelaskan dalam tiga bagian besar, yaitu penataan fisik di bagian gudang, peralatan yang mendukung kesehatan dan keselamatan kerja, serta fasilitas pendukung proses kerja. Kondisi tempat kerja yang dipersepsi karyawan terkait dengan arsitektur dan penampilan tempat kerja. Arsitektur tempat kerja ini termasuk ukuran dan tata letak tempat kerja, pembagian tempat kerja, pengaturan kantor, warna dinding (Idrus, 2006). Penampilan fisik yang ditunjukkan dalam penataan fisik spareparts di gudang masih perlu dibenahi karena dari segi keamanan masih membahayakan karyawan. Misalkan penataan velg masih ditata dengan menggunakan palet yang berpotensi terjadi kecelakaan kerja. Saat membersihkan spareparts lainnya masih menggunakan lap sehingga proses kerja menjadi lambat. Sebenarnya, lap tersebut bisa digantikan dengan menggunakan kompresor agar mempermudah dan mempercepat pekerjaan.

Penataan fisik tempat kerja juga terkait dengan masalah kesehatan dan keselamatan kerja di bagian produksi. Karyawan beberapa kali mengalami kecelakaan kerja di area produksi, namun kotak P3K berada di kantor yang berjarak cukup jauh dari area produksi. Sama seperti yang disampaikan oleh Jewel dan Siegall (dalam Idrus, 2006) bahwa tata letak tempat kerja beserta peralatan di dalamnya termasuk pembagian dan pengaturan kantor seharusnya diatur untuk mempermudah proses kerja. Hal ini menyebabkan tidak efisiennya pertolongan pertama yang diberikan pihak perusahaan ketika karyawan mengalami kecelakaan kerja. Di sisi lain, standar kesehatan dan keselamatan kerja tidak semuanya diabaikan oleh perusahaan melainkan oleh karyawan itu sendiri. Helm kerja serta jaket pengaman sudah disediakan oleh perusahaan, namun tidak digunakan oleh karyawan.

Kekurangan terhadap lingkungan fisik terjadi pula pada bagian produksi. Bagian produksi kekurangan alat untuk mendukung proses produksi seperti ketidaksediaan alat press, mesin tekuk, dan mesin roll. Kondisi ini membuat karyawan kurang merasa nyaman dalam bekerja karena kekurangan sarana dan prasarana pendukung, kurangnya perhatian terhadap kesehatan dan keselamatan kerja serta kekurangan alat tersebut. Dampaknya, proses produksi menjadi terhambat karena para karyawan harus saling menunggu giliran dalam menggunakan suatu alat. Pekerjaan pun menjadi tertunda dan pengerjaan produksi tidak sesuai dengan perjanjian. Keluhan dari customer pun menjadi konsekuensi yang tidak bisa dihindari. Fasilitas dan sarana prasarana yang kurang mendukung proses kerja akan menciptakan iklim kerja yang tidak kondusif dan berdampak pada turunnya kinerja (Wirawan, 2008; Li \& Mahadevan, 2017; dan Berberoglu, 2018). 
Dalam iklim organisasi itu sendiri terdapat sekumpulan perilaku, nilai-nilai, serta praktek langsung dari organisasi yang terjadi secara rutin (Adenike, 2011). Praktek rutin ini kemudian berubah menjadi pola kebiasaan yang dilakukan oleh organisasi. Pola kebiasaan merupakan sikap yang ditunjukkan secara berulang kali dalam organisasi. Wirawan (2008) menyebutkan bahwa pola kebiasaan ini jika dilakukan secara terus menerus akan menjadi tradisi yang akan berpengaruh terhadap pola pikir dan pola perilaku. Pola ini kemudian akan membentuk persepsi anggota organisasi yang berpengaruh terhadap terciptanya iklim di dalam organisasi (Stinger, 2002). Pola kebiasaan yang diidentifikasi dalam penelitian ini terdiri dari kebiasaan rapat, dan kebiasaan meminjam uang di perusahaan.

Rapat sering diadakan oleh atasan kepada bawahan. Rapat ini menjadi kegiatan rutin dalam proses kerja di PT. Karoseri SUS. Rapat ini diadakan dengan waktu yang cukup lama namun tidak membahas hal yang penting. Selain itu pula, rapat ini tidak menghasilkan suatu action plan sehingga pada akhirnya kehilangan esensi dari rapat itu. Esensi dari rapat yang dimaksud adalah rapat digunakan untuk membahas permasalahan yang terjadi, merencanakan penyelesaiannya, kemudian dipraktekkan lalu dievaluasi. Kebiasaan ini kemudian berimbas pada terlambatnya proses kerja. Para karyawan di berbagai divisi sering mengeluhkan kebiasaan rapat yang terlalu panjang ini karena waktu untuk mencari customer menjadi terpotong, proses produksi menjadi tertunda, ataupun proses akuntansi dan keuangan menjadi terganggu. Pola kebiasaan yang kedua adalah karyawan meminjam uang secara pribadi dari perusahaan. Perusahaan memberikan bantuan kepada karyawan jika ada yang ingin meminjam. Sudah dari lama karyawan melakukan pinjaman dan sekarang ini banyak yang masih melakukan hal tersebut. Namun, hal ini kemudian menjadi kebiasaan dan menurut pendapat atasan, hal ini adalah hal yang kurang baik. Selain itu juga, dampak lain yang muncul, yaitu pengontrolannya rumit.

Iklim organisasi yang terjadi pada PT. Karoseri SUS belum cukup kondusif. Kondisi iklim yang cukup kondusif ini diperlihatkan dengan beberapa kondisi yang tergambarkan dalam dimensi-dimensi pembentuk iklim organisasi seperti penjelasan di atas. Kondisi iklim ini masih berbanding terbalik dengan kondisi ideal yang diharapkan, yaitu adanya kejelasan penerapan sistem manajemen termasuk penerapan peraturan dan prosedur kerja yang jelas, deskripsi kerja dan target kerja yang terukur, penerapan sistem imbalan yang setara, hubungan baik dengan atasan, rekan kerja serta stakeholder lainnya, sarana dan prasarana yang mendukung serta pola kebiasaan yang berakibat negatif pada proses kerja. Perusahaan ini perlu melakukan evaluasi dan perubahan terhadap segala kebijakan dan berbagai hal terkait iklim organisasi. Iklim organisasi yang kondusif dan positif harus mampu diciptakan di PT. Karoseri SUS.

Iklim yang kondusif dapat membuat lingkungan dan kondisi kerja menyenangkan, mendukung terbentuknya kinerja yang lebih maksimal, serta menciptakan kepuasan dan komitmen kerja dari para anggota (Dewi \& Prihatsanti, 2010; Dewi \& Prasetyo, 2017). Iklim organisasi yang kondusif hanya dapat tercipta secara efektif jika semua sistem dapat terintegrasi dan memiliki kesinambungan yang positif. Dukungan dan dedikasi dari para karyawan serta peran aktif dari pihak manajerial termasuk kontribusi dari pihak eksternal seperti customer dan konsultan menjadi penentu dalam mendesain iklim organisasi yang cocok (best-fit) dengan kondisi, nilai, misi dan visi organisasi (Stinger, 2002; Wirawan, 2008; Permarupan et al, 2013; Muthukumar \& Guru, 2016; Li \& Mahadevan, 2017). Iklim organisasi yang kondusif perlu dibangun, dipertahankan dan dikembangkan oleh PT. Karoseri SUS. Identifikasi terhadap dimensi pembentuk iklim organisasi yang sudah dilakukan akan mempermudah para pemangku kepentingan, pelaksana lapangan, dan seluruh pihak terkait organisasi dalam menciptakan iklim yang kondusif.

\section{KESIMPULAN}

Iklim organisasi pada perusahaan manufaktur karoseri PT. Karoseri SUS dibentuk oleh empat dimensi, yaitu penerapan sistem manajemen, lingkungan sosial, lingkungan fisik, dan pola kebiasaan. Setiap dimensi tersebut mengandung komponen penyusunnya. Dimensi penerapan sistem manajemen terdiri dari komponen standard dan prosedur kerja, sistem imbalan, dan sistem birokrasi. Dimensi lingkungan sosial terdiri dari komponen hubungan antara atasan dengan bawahan, hubungan antara rekan kerja, dan hubungan antara organisasi dengan pihak luar. Dimensi lingkungan fisik terdiri dari komponen sarana dan prasarana yang mendukung proses kerja, serta tempat kerja. dimensi pola kebiasaan terdiri dari berbagai sikap-sikap yang biasa dilakukan organisasi serta yang berdampak pada proses kerja.

Penelitian ini bisa menjadi salah satu acuan bagi organisasi termasuk PT. Karoseri SUS dalam membentuk iklim organisasi yang kondusif, seperti membuat sistem manajemen yang lebih terstruktur, sistematis dan terstandar sehingga seluruh proses kerja menjadi lebih jelas dan transparan. Selain itu, peraturan atau kebijakan yang sudah disepakati perlu dijalankan oleh seluruh anggota organisasi termasuk pihak manajerial. Diharapkan 
pula agar para karyawan lebih aktif menyampaikan aspirasi kepada atasan berdasarkan alur birokrasi yang ada sehingga tercipta komunikasi dua arah antara pihak karyawan dan manajerial. Bagi pihak human resources department dapat membuat kegiatan yang melibatkan seluruh anggota perusahaan seperti kegiatan fun-outbound atau sekadar gala dinner dengan tujuan menstimulasi rasa kebersamaan antara seluruh anggota organisasi di semua level jabatan sehingga iklim organisasi menjadi lebih kondusif. Pihak organisasi pun perlu mengidentifikasi pola-pola kebiasaan yang mungkin ada di organisasi yang dapat menghambat produktivitas serta kinerja individu maupun organisasi secara keseluruhan. Untuk para peneliti di pengembangan organisasi, agar lebih mendalami konsep teoritis mengenai iklim organisasi dan perusahaan manufaktur karoseri dengan cara lebih banyak melakukan riviu kajian pustaka.

\section{ACKNOLEDGEMENT}

Penulis mengucapkan terima kasih kepada seluruh pihak yang menjadi bagian dari penelitian ini, khususnya pihak perusahaan PT. Karoseri SUS dan civitas akademik bidang minat psikologi industri Fakultas Psikologi Unika Widya Mandala Surabaya atas berbagai masukan dan saran demi pengembangan penulisan artikel ini.

\section{DAFTAR PUSTAKA}

Abdurrochman, A. (2010). Analisis pengendalian kualitas pada pembuatan atap (roof) body mitsubishi prona di pt. karoseri agustus. Skripsi. Fakultas Teknik Universitas Pembangunan Nasional Veteran.

Astuti, S.D. (2010). Model person-organization fit (P-O fit model) terhadap kepuasan kerja, komitmen rrganisasional dan kinerja karyawan. Jurnal Bisnis dan Ekonomi, 17, (43), 43-60.

Bahrami, M. A, Barati, O, Ghoroghchian, M, Montazer-alfaraj, R, Ezzatabadi, M. R. (2016). Role of organizational climate in organizational commitment: The case of teaching hospitals. Osong Public Health Res Perpect, 7, (2), 96-100. doi: http://dx.doi.org/10.1016/j.phrp.2015.11.009.

Berberoglu, A. (2018). Impact of organizational climate on organizational commitment and perceived organizational performance: Empirical evidence from public hospitals. BMC Health Service Research, $18,399-407$.

Björkdahl, J dan Börjesson, S. (2011) Organizational climate and capabilities for innovation: a study of nine forest-based Nordic manufacturing firms. Scandinavian Journal of Forest Research, 26, (5), 488-500. doi: $10.1080 / 02827581.2011 .585997$.

Dewi, R.D dan Prasetyo, A.R. (2017). Hubungan antara iklim organisasi dengan keterikatan kerja pada karyawan pt angkasa pura 1 (persero) kantor cabang semarang. Jurnal Empati, 6, (1), 80-85.

Dewi, K.S., Prihatsanti, U. (2010). Hubungan antara iklim organisasi dan organizational citizenship behavior (OCB) pada guru sd negeri di kecamatan mojolaban sukoharjo. Jurnal Psikologi Undip, 7, 11-17.

Gabungan Industri Kendaraan Bermotor Indonesia tentang Indonesian Automobile Industri Data. Sumber data: https://www.gaikindo.or.id/indonesian-automobile-industry-data.

Idrus, M. (2008). Implikasi iklim organisasi terhadap kepuasan kerja dan kualitas kehidupan kerja karyawan. Jurnal Psikologi Universitas Diponegoro, 3, (1), 94-106

Li, Y. P, dan Mahadevan, A. (2017). A study on the impact of organisational climate on employee performance in a malaysian consultancy, International Journal of Accounting \& Business Management, 5, (1), 1-13. doi: 24924/ijabm/2017.04/v5.iss1/1.13

Luthans, F. (2006). Perilaku organisasi (Organizational behaviour, 10 th edition). Penerjemah: V. Andhika, dkk. Yogyakarta: Andi Offset.

Mondy, R. W. (2010). Human resources management. New Jersey: Pearson Education, Inc.

Muthukumar, M, dan Guru, K. (2016). The impact of employees perception of organizational climate in manufacturing industry at kandanchavadi, chennai. International Journal of Commerce and Management Research, 2, (11), 31-33.

Permarupan, P. Y, Saufi, R.A, Kasim, R.S.R, dan Balakrishnan, B. KPD. (2013). The impact of organizational climate on employee's work passion and organizational commitment, Procedia - Social and Behavioral Sciences, 107, 85-95. doi: 10.1016/j.sbspro.2013.12.403.

Poerwandari, E. K. (1998). Pendekatan kualitatif dalam penelitian psikologi. Jakarta: Lembaga Pengembangan Sarana Pengukuran dan Pendidikan Psikologi (LPSP3) Fakultas Psikologi Universitas Indonesia.

Robbins, S. P., DeCenzo, D.A., Coulter, M., Anderson, I. (2017). Fundamentals of Management. Toronto: Pearson.

Sari, E. (2009). Pengaruh kompensasi dan iklim organisasi terhadap kepuasan kerja. Jurnal Administrasi dan Organisasi, 16, 18-24. 
Satwiko, P. (1991). Perancangan bangunan industry. Yogyakarta: Universitas Atmajaya.

Sayoga, D. D. G. (2018). The Influence of leadership and organizational climate of Eemployee performance through motivation as a mediation Variable. International Journal of Contemporary Research and Review, 9(08), 20986-20996. https://doi.org/10.15520/ijcrr/2018/9/08/571.

Silalahi, G.A. (2003). Metodologi penelitian dan studi kasus. Surabaya: Citramedia.

Stinger, R. (2002). Leadership and organizational cliamate: The cloud chamber effect. New Jersey: Prentice Hall.

Yani, A., Tunas, B., Entang, M. (2017). Transformational leadership, organizational climate, and work motivation in boosting teachers' performance. International Journal of Managerial Studies and Research, 5 (6), 43-50 